\title{
Tingkat Islamic Financial Literacy dan Penggunaan Fintech Terhadap Financial Inclusion UMKM Kawasan Pondok Pesantren di Kota Jombang
}

\author{
Lik Anah $^{1}$, Lilis Sugi Rahayu Ningsih ${ }^{2}$ \\ Universitas Hasyim Asy'ari Jombang \\ Email : lik.anah89@gmail.com ${ }^{1}$, lilissugi4@gmail.com ${ }^{2}$
}

\begin{abstract}
The UMKM in Islamic Boarding School area continue to experience an increase in financial transactions in line with the increase in banking financial services, especially Islamic banking financial services, for example: BPRS, Syariah Bank, BMT and Micro Waqf Banks which are located around the area. The purpose of this study is to find out the level of Islamic financial literacy and the use of Fintech of UMKM in the Islamic boarding school area in Jombang. This is based on the data that the number of research is included in associative research with purposive sampling technique of all UMKM which are located in the Islamic boarding school area in Jombang, with the criteria of UMKM which have used Fintech services and banking services as the requirement in the area of financial inclusion. The method used in this research is multiple linear regression analysis which is strengthened by qualitative analysis to find out the quality of financial inclusion. The results showed that Islamic financial literacy has a positive and significant effect on financial inclusion. The use of Fintech has a positive and significant effect on UMKM financial inclusion. Islamic financial literacy and the use of Fintech have a positive and significant effect on the financial inclusion of UMKM in the Islamic boarding school area in Jombang city.
\end{abstract}

Keywords : Islamic financial literacy; Fintec; Financial Inclusion; UMKM

Abstrak : UMKM di kawasan pondok pesantren terus mengalami peningkatan khusunyatransaksi keuangannya sejalan dengan bertambahnya layanan jasa keuangan perbankan terutama jasa keuangan perbankan syariah misalnya BPRS, Bank syariah, BMT dan bank wakaf mikro yang terdapat di sekitar kawasan tersebut. Tujuan dari penelitian ini adalah mengetahui tingkat Islamic financial literacy dan penggunaan fintech oleh UMKM di kawasan pondok pesantren di kota Jombang. Hal ini berdasarkan data bahwa jumlah Penelitian ini termasuk dalam penelitian asosiatif dengan teknik pengambilan sampel purposive sampling pada seluruh UMKM yang terdapat di kawasan pondok pesantren di kota Jombang dengan kriteria UMKM yang telah memanfaatkan jasa fintech dan telah memanfaatkan jasa layanan perbankan yang disyaratkan dalam lingkup inklusi keuangan. Metode yang digunakan dalam penelitian ini adalah analisis regresi linier berganda yang diperkuat dengan analisis kualitatif untuk mengetahui kualitas inklusi keuangan. Hasil penelitian menunjukkan bahwa Islamic financial literacy berpengaruh positif dan signifikan terhadap financial inclusion. Penggunaan fintech berpengaruh positif dan signifikan terhadap financial inclusion UMKM. Islamic financial literacy dan penggunaan fintech berpengaruh positif dan signifikan terhadap financial inclusion UMKM kawasan pondok pesantren di kota Jombang.

Kata Kunci : : Literasi Keuangan Islam; Fintech; Inklusi Keuangan; UMKM

\section{A. Pendahuluan}

Perkembangan UMKM (Usaha Mikro Kecil dan Menengah) di Indonesia semakin mendapatkan dukungan dari pemerintah dan perbankan. Dukungan yang diberikan dapat berupa kebijakan dan regulasi yang berpihak kepada pengembangan UMKM. Sedangakan dukungan dari perbankan dapat berupa penyaluran kredit kepada UMKM tersebut. Setiap tahunnya, kredit kepada UMKM mengalami pertumbuhan yang secara umum lebih tinggi dibandingkan dengan total kredit perbankan. Perbankan nasional maupun perbankan syariah memberikan andil yang cukup besar terhadap pengembangan UMKM termasuk dalam hal penyaluran kredit. Berbagai upaya dalam peningkatan inklusi keuangan telah banyak dilakukan oleh pemerintah maupun lembaga perbankan, salah satunya melalui fintech. Perkembangan Fintech di Indonesia di dominasi oleh Fintech payment (Kartuku,Coda Pay, Dll) sebanyak $41 \%$, sebagai market provisioning sebesar 12\%, Investment Management $11 \%$, Insurance 3\%, 
30\% sebagai lending (P2P) dan 3\% digunakan sebagai Capital Raising (Equity Crowdfunding). Saat ini terdapat 22 fintech P2P yang terdaftar di OJK dan 8 diantaranya telah mendapatkan Izin. Usaha untuk optimalisasi fintech dalam mendorong kemampuan UMKM di Indonesia harus terus di tingkatkan, hal ini dikarenakan fintech memiliki potensi dalam meningkatkan para pelaku UMKM yang pada akhirnya diharapkan dapat mendorong pemerataan tingkat kesejahteraan masyarakat menengah. ${ }^{1}$

Hasil indeks literasi keuangan syariah yang disampaikan oleh Bank Indonesia di 13 profinsi yang berbeda, diperoleh skor literasi sebesar 16,3\% masuk dalam kategori well literate, sufficient literate sebesar 27,2\%, less literate sebesar 32,5\% dan not literate $24,0 \%$. Dimana well literate menitikberatkan pada aspek prinsip dasar ekonomi syariah dan keuangan social syariah. Aspek yang memberikan kontribusi terbesar dalam pembangunan tingkat literasi syariah yaitu aspek nilai nilai ekonomi syariah yang diikuti oleh aspek lembaga keuangan social syariah dan kemampuan numerik. ${ }^{2}$

Kebutuhan penelitian tentang Islamic financial literacy juga tidak hanya dipengaruhi oleh faktor internal yang dari kebutuhan seorang muslim itu sendiri, tetapi juga dipengaruhi oleh faktor eksternal, misalnya ketersediaan instrument keuangan yang dapat meningkatkan kepedulian seseorang untuk membuat keputusan financial berdasarkan Islamic financial literacy $^{3}$. Dari sini dapat pula dipahami bahwa kemampuan seseorang dalam memahami financial literacy akan lebih meningkat jika ditunjang oleh kelengkapan dan ketersediaaan akses keuangan yang memadai dan terjangkau.

Central Bank of Nigeria menyatakan bahwa perkembangan inklusi keuangan membutuhkan dukungan kebijakan dari pemerintah beserta seluruh komponennya serta penyediaan layanan keuangan yang memadai yang dapat diakses oleh masyarakat secara umum. Penyediaan layanan yang memadai ini bias dikatakan sebagai balah satu bentuk dukungan yang dapat menjunjang perkembangan financial technology. Sekaligus memberikan gambaran bahwa financial technology dapat meningkatan inklusi keuangan masyarakat. ${ }^{4}$

Pencapaian inklusi keuangan dan pemanfaatan fintech tidak dapat dilakukan secara maksimal jika pelaku UMKM memiliki tingkat pengetahuan atau dalam hal ini financial literacy yang baik. Sehingga indentifikasi tingkat literacy keuangan yang baik sangat diperlukan agar kebijakan yang kan dibuat terkait peningkatan inklusi keuangan dapat dijalankan secara maksimal dan dapat tepat sasaran. Kaitannya dengan Islamic financial literacy melihat pada perkembangan jasa keuangan syariah yang terus memberikan layanan kepada masyarakat, yang dalam penelitian ini dikhususkkan pada UMKM di kawasan pondok pesantren dikarenakan kawasan pondok pesantren kental dengan pengembangan ilmu keagamaan dan segala kegiatan diharapkan sesuai dengan syariah, tidak terkecuali dalam hal pengelolaan dan pemahaman keuangan secara syariah.

Rumusan masalah dalam penelitian ini dapat dirumuskan sebagai menjadi (1) bagaimana pengaruh islamic financial literacy terhadap financial inclusion UMKM kawasan pondok pesantren di kota Jombang, (2) bagaimana pengaruh penggunaan fintech terhadap financial inclusion UMKM kawasan pondok pesantren di kota Jombang dan (3) bagaimana pengaruh 2016

${ }^{1}$ Departemen Pengembangan Akses Keuangan dan UMKM, Booklet Keuangan Inklusif, Bank Indonesia,

${ }^{2}$ Departemen Ekonomi and Keuangan, 'Literasi Ekonomi Syariah', Departemen Ekonomi dan Keuangan Syariah. Bank Indonesia, (2020).

${ }^{3}$ Rike Setiawati and others, 'Islamic Financial Literacy: Construct', Academy of Strategic Management Journal, 17.4 (2018): 1-12.

${ }^{4}$ Cental Bank, 'Financial Inclusion In Nigeria : Issues And Challenges', 45, 2013. 
islamic financial literacy dan penggunaan fintech terhadap financial inclusion UMKM kawasan pondok pesantren di kota Jombang.

Chen dan Volpe menyatakan bahwa financial literacy merupakan kemampuan seseorang untuk mengelola keuangan pribadi untuk mencapai kesejahteraan dalam hidupnya. Chen dan Volpe membagi literasi keuangan menjadi 4 indikator atau dimensi dari pengetahuan keuangan, diantaranya ialah pengetahuan keuangan dasar (basic financial knowledge), tabungan dan pinjaman (saving and borrowing), proteksi atau asuransi (insurance), investasi.

OECD/INFE menyatakan bahwa literasi keuangan mencakup tiga komponen penting dalam keuangan meliputi tiga hal yaitu pengetahuan euangan (Financial Knowledge), perilaku Keuangan (Financial Behaviour), sikap keuangan (Financial Attitude). Hsueh menyampaikan teknologi Keuangan atau Fintech, merupakan model baru layanan keuangan yang dikembangkan melalui inovasi teknologi informasi. Maka dalam hal ini financial technology dapat diartikan sebagai layanan yang menggabungkan teknologi dan keuangan dimana layanan ini menyediakan inovasi pada bisnis. Financial technology meliputi tiga tipe yaitu third-party payment systems merupakan istem pembayaran melalui pihak ketiga, Peer-to-Peer (P2P) Lending dan crowdfunding. ${ }^{6}$

Literasi ekonomi syariah didefinisikan sebagai pengetahuan dasar tentang prinsip ekonomi syariah dan keuangan (economic dan financial knowledge) menurut aturan islam atau syariah, memiliki keterampilan (financial skill) dan keyakinan (financial confident) dalam mengelola sumber keuangan (financial behavior) secara tepat untuk mencapai kesejahteraan (well being) dan keseimbangan dunia dan akhirat sesuai dengan tuntunan agama ${ }^{7}$. Islamic financial literacy dapat pula diartikan sebagai pengetahuan individu tentang keuangan, skills, attitude dan bagaimana seseorang tersebut mengelola keuangannya dengan menerapkan pembelajaran islam $^{8}$. Islamic Financial Literacy merupakan tingkat pengetahuan, kepedulian dan pemahamahan seorang individu terhadap pelayanan dan fundamental dari informasi keuangan islam sehingga mempengaruhi perilaku dalam menentukan keputusan keuangan islam yang sesuai. ${ }^{9}$

Otoritas Jasa Keuangan menyampaikan kelebihan dari Fintech antara lain melayani masyarakat Indonesia yang belum dilayani oleh industri keuangan tradisional karena ketatnya peraturan perbankan dan keterbatasan industri perbankan tradisional dalam melayani masyarakat di daerah tertentu, menjadi alternatif pendanaan selain jasa industri keuangan tradisional dimana saat ini masyarakat memerlukan alternatif pembiayaan yang lebih demokratis dan transparan. ${ }^{10}$

Kekurangan dari Fintech yang disampaikan oleh Otoritas Jasa Keuangan yaitu Fintech adalah pihak yang tidak memiliki lisensi untuk memindahkan dana serta kurang mapan dalam menjalankan usahanya dengan modal yang besar jika dibandingkan dengan bank, terdapat

\footnotetext{
${ }^{5}$ Peng Xue and others, 'Highly Efficient Measurement Technology Based on Hyper-Spectropolarimetric Imaging', Zhongguo Jiguang/Chinese Journal of Lasers, 43.8 (2016): 107-28

6 Miswan Ansori, 'Perkembangan Dan Dampak Financial Technology (Fintech) Terhadap Industri Keuangan Syariah Di Jawa Tengah', Wahana Islamika: Jurnal Studi Keislaman, 5.1 (2019): 31-45.

${ }^{7}$ Ekonomi and Keuangan Ekonomi, Departemen, and Keuangan. Literasi Ekonomi Syariah. Departemen Ekonomi dan Keuangan Syariah: Bank Indonesia, 2020.

${ }^{8}$ (Rahim,, S. H. A., Rashid, R. A., Hamed, A. B, 'Factor Analysis of Islamic Financial Literacy and Its Determinan: A Pilot Study', International Soft Science Conference (ISSC), (2016)

${ }^{9}$ Purnomo M. Antara, Rosidah Musa, and Faridah Hassan, 'Bridging Islamic Financial Literacy and Halal Literacy: The Way Forward in Halal Ecosystem', Procedia Economics and Finance, 37.16 (2016): 196-202

${ }^{10}$ Perbankan Indonesia, 'Booklet Perbankan Indonesia 2016', Otoritas Jasa Keuangan Departemen Perijinan Dan Informasi Perbankan, 3 (2016): 292.
} 
sebagaian perusahaan Fintech yang belum memiliki kantor fisik serta kurangnya pengalaman dalam menjalankan prosedur terkait sistem keamanan dan itegritas produknya

Strategi Nasional Keuangan Inklusif mendefinisikan keuangan inklusif sebagai hak setiap orang untuk dapat memiliki akses serta layanan penuh dari lembaga keuangan secara tepat waktu, nyaman, informatif, dan terjangkau biayanya, dengan menghormati harkat dan martabatnya. Layanan keuangan dapat digunakan oleh seluruh segmen masyarakat, dengan memberikan perhatian khusus kepada orang miskin, miskin produktif, pekerja migran dan penduduk yang berada di daerah terpencil. ${ }^{11}$

Peningkatkan akses masyarakat kepada lembaga keuangan tersebut tentunya merupakan masalah kompleksitas yang memerlukan koordinasi lintas sektoral yang melibatkan otoritas perbankan, jasa keuangan non bank dan kementerian atau lembaga lain yang menaruh perhatian pada upaya pengentasan kemiskinan, sehingga diperlukan kebijakan komprehensif serta menyeluruh dalam suatu Strategi Nasional Keuangan Inklusif.

Kerangka kerja umum keuangan inklusif dibangun di atas enam pilar yaitu pertama Pilar Edukasi Keuangan. Pilar ini bertujuan meningkatkan pengetahuan, kesadaran masyarakat tentang berbagai produk dan jasa keuangan yang terdapat dalam pasar keuangan formal dan aspek perlindungan konsumen serta pemahaman manajemen risiko. Ruang lingkup edukasi keuangan terdiri dari pengetahuan dan kesadaran tentang ragam produk dan jasa keuangan, pengetahuan dan kesadaran resiko produk keuangan, perlindungan nasabah dan ketrampilan pengelolaan keuangan.

Kedua Pilar Fasilitas Keuangan Publik. Pada pilar ini terdapat strategi yang mengacu pada kemampuan dan peran serta pemerintah dalam usaha penyediaan pembiayaan keuangan publik secara langsung maupun bersyarat untuk mendorong pemberdayaan ekonomi masyarakat. Inisiatif dalam pilar ini meliputi beberapa poin yaitu subsidi dan bantuan sosial, pemberdayaan masyarakat dan pemberdayaan UMKM.

Ketiga, Pilar Pemetaan Informasi Keuangan. Pilar 3 mempunyai tujuan meningkatkan kapasitas masyarakat terutama yang masuk dalam kategori tidak layak untuk menjadi layak atau dari unbankable menjadi bankable yang dilakukan oleh institusi keuangan normal, terutama kategori miskin produktif dan usaha mikro kecil. Inisiatif yang dilakukan di pilar ini meliputi peningkatan kapasitas (melalui penyediaan pelatihan dan bantuan teknis), sistem jaminan alternatif (lebih sederhana namun tetap memperhatikan risiko terkait), penyediaan layanan kredit yang lebih sederhana dan identifikasi nasabah potensial.

Empat, Pilar Kebijakan atau Peraturan yang mendukung. Dukungan kebijakan dari pemerintah maupun Bank Indonesia sangat dibutuhkan untuk meningkatkan akses layanan jasa keuangan dalam pelaksanaan program keuangan inklusif tersebut. Inisiatif yang digunakan untuk mendukung pilar ini meliputi: Kebijakan untuk mendorong sosialisasi produk jasa keuangan sesuai dengan kebutuhan masyarakat, menyusun skema produk yang sesuai dengan kebutuhan masyarakat, mendorong perubahan ketentuan dengan tetap memperhatikan prinsip kehatihatian secara proporsional, menyusun peraturan mekanisme penyaluran dana bantuan perbankan, memperkuat landasan hukum untuk meningkatkan perlindungan konsumen jasa keuangan, menyusun kajian keuangan inklusif untuk menentukan arah kebijakan yang berkelanjutan.

${ }^{11}$ UMKM, Departemen Pengembangan Akses Keuangan dan, Booklet Keuangan Inklusif, Bank Indonesia, 2016, h. 10 
Lima, pilar Fasilitas Intermediasi dan Saluran Distribusi. Pilar ini bertujuan meningkatkan kesadaran lembaga keuangan tentang keberadaan bagian yang potensional di masyarakat dan memperluas jangkauan layanan jasa keuangan dengan cara pemanfaatan metode distribusi alternatif. Aspek pada pilar ini meliputi; memfasilitasi forum intermediasi dengan cara mempertemukan lembaga keuangan dengan kelompok masyarakat produktif (layak dan unbanked) sebagai usaha untuk mengatasi 13 masalah informasi yang asimetris, meningkatkan kerjasama antara lembaga keuangan untuk meningkatkan skala usaha, eksplorasi berbagai kemungkinan produk layanan jasa dan saluran distribusi yang inovatif dengan cara tetap memberikan perhatian pada prinsip kehati-hatian.

Terakhir, Pilar Perlindungan Konsumen. Mempunyai tujuan agar masyarakat memiliki jaminan rasa aman dalam melakukan interaksi dengan institusi keuangan untuk memanfaatkan produk dan layanan jasa keuangan yang ditawarkan. Komponen pada pilar ini meliputi; transparansi produk, penanganan keluhan nasabah, mediasi dan edukasi konsumen. ${ }^{12}$

Indikator yang dapat dijadikan ukuran sebuah negara dalam mengembangkan keuangan inklusif adalah ketersediaan atau akses yang dilakukan dengan cara mengukur kemampuan penggunaan jasa keuangan formal dalam hal keterjangkauan fisik dan harga, penggunaan yang dilakukan dengan cara mengukur kemampuan penggunaan aktual produk dan jasa keuangan (keteraturan, frekuensi dan lama penggunaan), kualitas yang dilakukan dengan mengukur apakah atribut produk dan jasa keuangan telah memenuhi kebutan pelanggan, kesejahteraan yang dilakukan dengan mengukur dampak layanan keuangan terhadap tingkat kehidupan pengguna jasa. Hal ini sesuai dengan agenda penting perbaikan di Indonesia, dimana inklusi keuangan dapat mendorong pertumbuhan ekonomi, dapat mengurangi kesenjangan pendapatan masyarakat dan tentunya dapat menigkatkan kesejahteraan masyarakat. ${ }^{13}$

Beberapa hasil penelitian yang relevan dengan penelitian ini yaitu Penelitian Mutlu (2017) dengan menggunakan penelitian kuantitatif metode survey diketahui bahwa individu dengan tingkat financial literacy yang rendah berdasarkan pada Islamic Financial Literacy menunjukkan kebiasaan non-inclusion dalam system financialnya. ${ }^{14}$.

Penelitian Anwar dkk (2017) menggunakan metode pelatihan, In Depth Interwiew dan diskusi dalan format Focus Grup Discussion (FGD) dengan berbagai stakeholders yang terkait. Pada umumnya pelaku usaha pada Usaha Mikro Kecil dan Menengah (UMKM) sudah melakukan administrasi keuangan walau masih sederhana, sudah melakukan administrasi keuangan walau masih sederhana (uang masuk dan keluar) Seseorang dengan perilaku keuangan personal yang baik berarti telah mampu secara baik membuat penganggaran (budgeting) dalam aktivitas sehari-harinya. ${ }^{15}$

Selanjutnya penelitian dari Sohilauw (2015) yang menggunakan metode riset eksplanasi (explanatory) yang dilakukan dalam dua tahap. Tahap pertama lebih menekankan pada pengumpulan dan analisis data kuantitatif kemudian dilanjutkan dengan pendekatan kualitatif untuk menjelaskan lebih lanjut temuan kuantitatif, dengan subjek penelitiannya adalah UKM.

12 UMKM, Departemen Pengembangan Akses Keuangan dan, Booklet Keuangan Inklusif, Bank Indonesia, 2016

${ }^{13}$ Buletin SNKI, 'Negara Hadir Perkuat Ekonomi Kerakyatan Melalui Kur Khusus Peternakan Rakyat', 2019, 1-10.

${ }^{14}$ Bunyamin Er, 'Financial Inclusion and Islamic Finance: A Survey of Islamic Financial Literacy Index', Uluslararası Íslam Ekonomisi ve Finansı Araştırmaları Dergisi, 3.2 (2017)

${ }^{15}$ Jurnal Riset and others, 'Keuangan Inklusif Dan Literasi Keuangan ( Studi Pada Sentra Industri Kecil Di Jawa Timur )', 17.2 (2017): 273-82. 
Hipotesis yang diangkat dalam penelitian ini yaitu (H1) Islamic financial literacy berpengaruh terhadap financial inclusion UMKM, (H2) Penggunaan Fintech berpengaruh terhadap financial inclusion UMKM dan (H3) Islamic financial literacy dan penggunaan fintech terhadap financial inclusion UMKM

\section{B. Metode Penelitian}

Penelitian ini merupakan penelitian asosiatif menggunakan metode analisis regresi linier berganda dengan menggunakan pendekatan kuantitatif. Sampel penelitian dilakukan secara purposive sampling pada seluruh UMKM yang terdapat di kawasan pondok pesantren di kota Jombang dengan kriteria UMKM yang telah memanfaatkan jasa fintech, telah memanfaatkan jasa layanan perbankan yang disyaratkan dalam lingkup inklusi keuangan sejumlah 40 UMKM.

Pengumpulan data menggunakan teknik dokumentasi, wawancara dan yang utama yaitu menggunakan kuisioner yang dibagikan pada responden penelitian yang disusun menggunakan skala likert dengan skala pengukuran 1 sampai 5. Lokasi penelitian yaitu pada UMKM kawasan pondok pesantren di kota Jombang meliputi Pondok Pesantren Tebuireng, Pondok Pesantren Darul Ulum, Pesantren Mambaul Maarif dan Pondok Pesantren Bahrul Ulum dengan waktu penelitian dari bulan April sampai September 2020.

Teknik analisis data diawali dengan melakukan uji kualitas data yaitu uji validitas dan realibiltas untuk menguji kelayakan kuesioner yang telah disusun sebagai instrument penelitian. Setelah diperoleh hasil penelitian dilanjutkan dengan uji asumsi klasik yaitu uji normalitas, uji heterokedastisitas, uji multikolinieritas dan uji autokorelasi. ${ }^{16}$

Uji regresi linier berganda dilakukan jika data yang diperoleh telah bebas dari ketentuan uji asumsi klasik yang telah dilakukan. Uji hipotesis menggunakan uji t (uji parsial) dan uji $\mathrm{F}$ (uji simultan), untuk kemudian dilanjutkan uji koefisien determinasi untuk mengetahui besarnya pengaruh variabel independen terhadap variabel dependen. ${ }^{17}$

Tabel 1. Blue print variabel penelitian

\begin{tabular}{|c|c|ll|}
\hline No & Variabel & \multicolumn{2}{|c|}{ Indikator } \\
\hline 1 & $\begin{array}{c}\text { Islamic Financial } \\
\text { literacy }\end{array}$ & $\begin{array}{l}\text { a. } \\
\text { b. }\end{array}$ & Pengetahuan keuangan \\
& & c. & Sikap keuangan \\
\hline 2 & Fintech & a. & Sistem pembayaran melalui pihak ketiga (Third-party \\
& & payment systems) \\
& & b. & Peer-to-Peer (P2P) Lending \\
& & c. & Crowdfunding \\
\hline 3 & Financial Inclusion & a. & Akses (access) \\
& & b. Penggunaan (usage) \\
& & c. & Kualitas (quality) \\
& & d. & Kesejahteraan \\
\hline
\end{tabular}

Sumber: Data diolah, 2020.

\section{Hasil dan Pembahasan}

\section{Karakteristik responden}

Karakteristik responden berdasarkan jenis kelamin sesuai jumlah dan persentasenya, terbanyak adalah laki-laki sebesar 21 (52,5\%) dan sisanya perempuan sebesar 19 (47,5\%).

${ }^{16}$ Ghozali, Aplikasi Analisis Multivariete Dengan Program IBM SPSS. Semarang: Badan Penerbit Universitas Diponegoro, 2016. h. 9

${ }^{17}$ Sugiyono, Metode Penelitian Kuantitatif, Kualitatif, Dan R\&D, Bandung: Alfabetha, 2015. 
Sehingga mayoritas responden dalam penelitian ini adalah laki-laki. Karakteristik responden berdasarkan lama Usaha, mayoritas responden memiliki lama berjalannya usaha $<1$ tahun sebanyak 16 UMKM (40\%). Antara 1-5 tahun sebanyak 14 UMKM (35\%), 6-10 tahun sebanyak 5 UMKM (12,5\%) dan >10 tahun sebanyak 5 UMKM (12,5\%). Sehingga dapat diketahui bahwa pada berbagai kurun waktu lamanya usaha, responden telah menjalankan usaha kurang dari setahun sampai lebih dari 10 tahun. Mayoritas responden sering menggunakan layanan fintech berupa tabungan sebanyak 27 UMKM (67,5\%). Sisanya menggunakan layanan fintech berupa transfer sebanyak 5 UMKM (12,5\%), pinjaman/kredit sebanyak 5 UMKM (12,5\%), dana dari Bu Nyai hanya 1 UMKM ((2,5\%), pom mini hanya 1 UMKM ((2,5\%), dan yang tidak menggunakan layanan fintech hanya 1 UMKM $(2,5 \%)$. Melalui table diatas dapat diketahui bahwa layanan financial technologi dalam bentuk produk tabungan lebih sering digunakan oleh pelaku UMKM. Karakteristik responden berdasarkan jenis platform fintech yang pernah digunakan, sebanyak 27 UMKM $(67,5 \%)$ menggunakan jenis platform fintech berupa aplikasi OVO. Sisanya menggunakan jenis layanan fintech berupa mobile banking sebanyak 5 UMKM (12,5\%), Link Aja sebanyak 5 UMKM (12,5\%), yang menggunakan tunai hanya 1 UMKM $(2,5 \%)$, koperasi hanya 1 UMKM (2,5\%), dan yang tidak pernah menggunakan jenis platform fintech hanya 1 UMKM $(2,5 \%)$. Artinya mayoritas responden pelaku UMKM dalam penelitian ini sebagain besar menggunakan platform fintech OVO.

\section{Distribusi Jawaban Responden}

Penentuan kelas atas pernyataan responden terhadap variabel penelitian adalah sebagai berikut yaitu Sangat rendah interval 1,00 - 1,80, Rendah 1,81 - 2,60, Cukup tinggi 2,61 - 3,40, Tinggi 3,41 - 4,20, Sangat tinggi 4,21 - 5,00. Berdasarkan penentuan tersebut terdapat 8 item untuk variabel penggunaan fintech. Diperoleh rata-rata indikator keseluruhan dengan nilai 2,18 termasuk kriteria rendah. Nilai tertinggi terletak pada item pernyataan nomor 1 "Saya mengunduh aplikasi jasa keuangan/system pembayaran online untuk memperlancar transaksi usaha dan keuangan" termasuk kriteria rendah. Dan nilai terendah terletak pada item pernyataan nomor 7 "Penggunaan layanan financial technology dapat memudahkan pengelolaan keuangan mulai dari pembiayaan, pembayaran dan pengelolaan keuangan"dengan nilai rata-rat sebesar 2,10 termasuk kriteria rendah.

Berdasarkan pengolahan 8 item variabel penggunaan fintech, diperoleh rata-rata indikator keseluruhan dengan nilai 2,18 termasuk kriteria rendah. Nilai tertinggi terletak pada item pernyataan nomor 1 "Saya mengunduh aplikasi jasa keuangan/system pembayaran online untuk memperlancar transaksi usaha dan keuangan" termasuk kriteria rendah. Dan nilai terendah terletak pada item pernyataan nomor 7 "Penggunaan layanan financial technology dapat memudahkan pengelolaan keuangan mulai dari pembiayaan, pembayaran dan pengelolaan keuangan"dengan nilai rata-rat sebesar 2,10 termasuk kriteria rendah.

Sementara terdapat 8 item untuk variabel Financial Inclusion UMKM. Diperoleh rata-rata indikator keseluruhan dengan nilai rata-rata 2,01 termasuk dalam kriteria nilai rendah. Nilai tertinggi terletak pada item pernyataan nomor 2 "Layanan jasa keuangan yang telah diperoleh mudah untuk diakses dan dijalankan" dengan perolehan nilai rata-rata sebesar 2,13 termasuk dalam kriteria nilai rendah. Sedangkan nilai terendah terletak pada item pernyataan nomor 3 "Layanan produk dan jasa keuangan perbankan dapat digunakan kapan saja sesuai dengan kebutuhaan transaksi" dengan perolehan nilai rata-rata sebesar 1,83 termasuk kriteri nilai rendah. 


\section{Uji Kualitas Data}

\section{a. Uji Validitas}

Hasil analisis menunjukkan semua butir pernyataan pada tingkat Islamic financial literacy, Penggunaan fintech dan financial inclusion UMKM dinyatakan valid atau dapat digunakan karena Rhitung > Rtabel $(0,3120)$ sehingga dapat dikatakan memenuhi syarat validitas

\section{b. Uji Reliabilitas}

Menunjukkan bahwa nilai Cronbach's Alpha > 0,7 dari ketiga variabel tingkat Islamic financial literacy, penggunaan fintech dan financial inclusion UMKM dapat dikatakan Reliabel.

\section{Uji Asumsi Klasik}

\section{a. Uji Normalitas}

Berdasarkan pada uji normalitas dianalisis menggunakan Kolmogorov-Smirnov, hasil tabel otput SPSS menunjukkan nilai Kolmogorv-Smirnov 0,200 >0,05. Maka dapat disimpulkan bahwa nilai residual berdistribusi normal. Begitu pula dengan Probability Plotter titik-titik data terletak di sekitar garis diagonal sehingga dikatakan normalitas terpenuhi atau dikatakan normal.

\section{b. Uji Multikolinieritas}

Hasil Uji Multikolinieritas menunjukkan bahwa nilai tolerance $0,610 \geq 0,10$ maka data hasil penelitian tidak terjadi multikolinieritas dengan hasil perhitngan nilai VIF adalah 1,640 yang menunjukkan bahwa tidak terjadi multikolinieiritas

\section{c. Uji Heteroskedastisitas}

Hasil uji heteroskedatisitas menunjukkan bahwa tidak terbentuk pola tertentu, serta titik titik menyebar di atas dan di bawah angka 0 pada sumbu Y, maka tidak terjadi gejala heteroskedastisitas.

\section{Analisis regresi linier berganda}

Pengolahan data yang dilakukan mengahsilkan tabel berikut untuk kemudian dianalisis hasil pengaruh antar variabelnya:

Tabel 2. Analisis Regresi Linier Berganda

\begin{tabular}{|c|c|c|c|c|c|c|c|c|}
\hline \multicolumn{9}{|c|}{ Coefficients $^{\mathrm{a}}$} \\
\hline \multirow{2}{*}{\multicolumn{2}{|c|}{ Model }} & \multicolumn{2}{|c|}{$\begin{array}{l}\text { Unstandardized } \\
\text { Coefficients }\end{array}$} & \multirow{2}{*}{$\begin{array}{c}\text { Standardized } \\
\text { Coefficients } \\
\text { Beta }\end{array}$} & \multirow[b]{2}{*}{$\mathrm{t}$} & \multirow[b]{2}{*}{ Sig. } & \multicolumn{2}{|c|}{$\begin{array}{l}\text { Collinearity } \\
\text { Statistics }\end{array}$} \\
\hline & & $\mathrm{B}$ & $\begin{array}{l}\text { Std. } \\
\text { Error }\end{array}$ & & & & Tolerance & VIF \\
\hline \multirow[t]{3}{*}{1} & (Constant) & .464 & 1.957 & & .237 & .814 & & \\
\hline & $\begin{array}{l}\text { TINGKAT ISLAMIC } \\
\text { FINANCIAL LITERACY }\end{array}$ & .671 & .121 & .623 & 5.549 & .000 & .610 & 1.640 \\
\hline & $\begin{array}{l}\text { PENGGUNAAN } \\
\text { FINTECH }\end{array}$ & .342 & .127 & .303 & 2.700 & .010 & .610 & 1.640 \\
\hline
\end{tabular}

Sumber: Data diolah, 2020.

Persamaan regresi linier berganda berdasarkan table coefficients diatas adalah sebagai berikut:

$$
\begin{gathered}
Y=a+b_{1} X_{1}+b_{2} X_{2}+e \\
Y=0,464+0,671 X_{1}+0,342 X_{2}+e
\end{gathered}
$$

Keterangan:

a. Koefisien $\mathrm{a}=0,464$ 
Dari persamaan regresi linier berganda di atas, maka diperoleh nilai konstaanta sebesar 0,464. Artinya, jika variabel Financial Inclusion UMKM tidak berpengaruh oleh kedua variabel bebas yaitu Tingkat Islamic Financial Literacy dan Penggunan Fintech bernilai nol, maka besarnya rata rata Financial Inclusion UMKM (Y) tetap sebesar 0,464.

b. Koefisien $b_{1}=0,671$

Koefisien regresi untuk variabel bebas $\left(\mathrm{x}_{1}\right)$ bernilai positif, menunjukkan bahwa adanya hubungan yang searah Tingkat Islamic Financial Literacy $\left(\mathrm{X}_{1}\right)$ dengan Financial Inclusion UMKM (Y). koefisien regresi linier Tingkat Islamic Financial Literacy $\left(\mathrm{X}_{1}\right)$ sebesar 0,671, artinya jika Tingkat Islamic Financial Literacy mengalami peningkatan, maka Financial Inclusion UMKM akan meningkat sebesar 0,671.

c. Koefisien $b_{2}=0,342$

Koefisien regresi untuk variabel bebas $\left(\mathrm{X}_{2}\right)$ bernilai positif, menunjukkan bahwa adanya hubungan yang searah antara Penggunaan Fintech $\left(\mathrm{X}_{2}\right)$ dengan Financial Inclusion UMKM (Y). koefisien regresi linier penggunaan fintech $\left(\mathrm{X}_{2}\right)$ sebesar 0,342 , artinya jika Penggunaan Fintech mengalami peningkatan maka Financial Inclusion UMKM akan meningkat sebesar 0,342 .

\section{Uji Hipotesis \\ a. Uji t (parsial)}

Tabel 3. Hasil Uji t (Parsial)

\begin{tabular}{|c|c|c|c|c|c|c|c|c|}
\hline \multicolumn{9}{|c|}{ Coefficients $^{\mathrm{a}}$} \\
\hline & \multirow[b]{2}{*}{ Model } & \multicolumn{2}{|c|}{$\begin{array}{l}\text { Unstandardized } \\
\text { Coefficients }\end{array}$} & \multirow{2}{*}{$\begin{array}{c}\text { Standardized } \\
\text { Coefficients } \\
\text { Beta }\end{array}$} & \multirow[b]{2}{*}{$\mathrm{t}$} & \multirow[b]{2}{*}{ Sig. } & \multicolumn{2}{|c|}{$\begin{array}{l}\text { Collinearity } \\
\text { Statistics }\end{array}$} \\
\hline & & $\mathrm{B}$ & $\begin{array}{l}\text { Std. } \\
\text { Error }\end{array}$ & & & & Tolerance & VIF \\
\hline \multirow[t]{3}{*}{1} & (Constant) & .464 & 1.957 & & .237 & .814 & & \\
\hline & $\begin{array}{l}\text { TINGKAT ISLAMIC } \\
\text { FINANCIAL LITERACY }\end{array}$ & .671 & .121 & .623 & 5.549 & .000 & .610 & 1.640 \\
\hline & $\begin{array}{l}\text { PENGGUNAAN } \\
\text { FINTECH }\end{array}$ & .342 & .127 & .303 & 2.700 & .010 & .610 & 1.640 \\
\hline
\end{tabular}

Sumber: Data diolah, 2020.

Dari hasil uji SPSS diatas untuk mengetahui pengaruh variabel bebas tingkat Islamic financial literacy $\left(\mathrm{X}_{1}\right)$ dan penggunaan fintech $\left(\mathrm{X}_{2}\right)$ terhadap financial inclusion UMKM (Y) yaitu variabel terikat dilakukan uji t. Pengujian secara parsial dpaat dilihat dari uji t, apabila nilai probabilitasnya $<0,05$, Ho ditolak yang berarti ada pengaruh yang signifikan.

Berdasarkan hasil uji parsial untuk variabel tingkat Islamic financial literacy diperoleh $\mathrm{t}$ hitung = 5,549 dengan nilai signifikansi sebesar 0,000 $<0,05$ maka Ho ditolah dan Ha diterima. Hal ini menunjukkan bahwa secara parsial $\mathrm{H}_{1}$ yang menyatakan bahwa ada pengaruh tingkat Islamic financial literacy terhadap financial inclusion UMKM Kawasan Pondok Pesantren di Kota Jombang.

Berdasarkan hasil uji parsial untuk Penggunaan Fintech diperoleh t hitung $=2,700$ dengan nilai signifikansi sebesar 0,010 $<0,05$ maka Ho ditolah dan Ha diterima. Hal ini menunjukkan bahwa secara parsial $\mathrm{H}_{1}$ yang menyatakan bahwa ada pengaruh penggunaan fintech terhadap financial inclusion UMKM Kawasan Pondok Pesantren di Kota Jombang.

\section{b. Uji F (Simultan)}

Dari hasil perhitungan statistik yang menggunakan SPSS yang tertera pada Table 4. diperoleh nilai $\mathrm{F}$ sebesar 46,588 dengan tingkat signifikansi 0,000. Nilai signifikansi yang 
dihasilkan tersebut lebih kecil dari 0,05. Hal ini berarti bahwa variabel financial inclusion UMKM (Y) dapat dijelaskan secara signifikansi oleh Tingkat Islamic Financial Literacy $\left(\mathrm{X}_{1}\right)$ dan penggunaan fintech $\left(\mathrm{X}_{2}\right)$. Jadi dapat disimpulkan bahwa tingkat Islamic financial literacy $\left(\mathrm{X}_{1}\right)$ dan penggunaan fintech secara simultan berpengaruh signifikan terhadap financial inclusion UMKM Kawasan Pondok Pesantren di Kota Jombang.

Tabel 4. Hasil Uji Statistik F (Simultan)

\begin{tabular}{|c|c|r|r|r|r|r|}
\hline \multicolumn{8}{|c|}{ ANOVA $^{\mathrm{a}}$} \\
\hline \multirow{2}{*}{1} & Model & Sum of Squares & df & Mean Square & F & Sig. \\
\cline { 2 - 7 } & Regression & 1266.839 & 2 & 633.419 & 46.588 & $.000^{\mathrm{b}}$ \\
\cline { 2 - 7 } & Residual & 503.061 & 37 & 13.596 & & \\
\cline { 2 - 7 } & Total & 1769.900 & 39 & & & \\
\hline \multicolumn{7}{|c|}{ A. Dependent Variable: Financial Inclusion Umkm } \\
\hline \multicolumn{7}{|c|}{ B. Predictors: (Constant), Penggunaan Fintech, Tingkat Islamic Financial Literacy } \\
\hline
\end{tabular}

Sumber: Data diolah, 2020

\section{c. Uji Koefisien Determinasi $\left(\mathbf{R}^{2}\right)$}

Tabel 5. Hasil Uji Koefisien Determinasi $\left(\mathbf{R}^{2}\right)$

\begin{tabular}{|c|c|r|c|r|}
\hline \multicolumn{5}{|c|}{ Model Summary $^{\mathrm{b}}$} \\
\hline Model & $\mathrm{R}$ & R Square & $\begin{array}{c}\text { Adjusted R } \\
\text { Square }\end{array}$ & $\begin{array}{c}\text { Std. Error of } \\
\text { the Estimate }\end{array}$ \\
\hline 1 & $.846^{\mathrm{a}}$ & .716 & .700 & 3.687 \\
\hline
\end{tabular}

Hasil uji koeifisien determinasi pada tabel diatas nilai yang dijadikan acuan koefisien determinasi adalah nilai pada Adjuster R Square yaitu sebesar 0,700 artinya variabel tingkat Islamic financial literacy dan penggunaan fintech mempengaruhi financial inclusion UMKM sebesar $70 \%$ sedangkan sisanya 30\% dipengaruhi oleh variabel lain yang tidak disebutkan dalam penelitian ini.

\section{Pengaruh Islamic financial literacy terhadap financial inclusion UMKM kawasan pondok pesantren di kota Jombang}

Hasil pengujian statistik melalui uji t menunjukkan bahwa tingkat Islamic financial literacy mempengaruhi financial inclusion UMKM kawasan pondok pesantren di Kota Jombang. Menggunakan indicator pengetahuan keuangan, perilaku keuangan dan sikap keuangan yang dijabarkan kedalam beberapa item pernyataan dapat diketahui bahwa tingkat Islamic financial literacy UMKM kawasan pondok pesantren di Kota Jombang masuk dalam kriteria rendah yang dianalisis melalui distribusi jawaban responden. Pengaruh yang ditunjukkan oleh variabel ini bernilai positif dan signifikan bermakna jika terjadi perubahan pada tingkat Islamic financial literacy UMKM makan akan mempengaruhi perubahan pada financial inclusion UMKM tersebut. Pengaruh positif tersebut dikarenakan meskipun Islamic financial literacy UMKM tersebut masih dalam kategori less literate namun pengalaman menjalankan usaha dan berdiri dalam kawasan pesantren memberikan pengetahuan dan kemampuan UMKM tersebut memahami Islamic financial literacynya.

Pengetahuan literasi keuangan meliputi menyusun catatan anggaran, menentukan skala priorotas dan menyesuaikan pendapatan serta pengeluaran yang diterima. Selain itu perilaku keuangan dalam Islamic financial literacy nampak dalam perubahan penerimaan dan pengeluaraan pada saat kondisi ekonomi kurang stabil atau saat terjadi inflasi dan dampak perilaku boros terhadap keuangan mereka. Sikap keuangan Nampak dalam ketaatan membayar pajak karena merupakan kewajiban warga negara dan juga sesuai dengan nilai islam. Melalui observasi yang dilakukan juga diketahui bahwa selain membayar pajak, beberapa pelaku 
UMKM tersebut juga mengetahui jenis pajak yang akan mereka bayarkan. Perwujudan lainnya tentang Islamic financial literacy yaitu kesadaran untuk menyisihkan hasil usaha untuk modal dan keberlangsungan usaha, hal menarik lainnya yaitu berkaitan dengan keberlangsungan usaha para pelaku UMKM juga memberikan perhatian untuk menyisihkan keuangan di jalur agama misalnya untuk berinfaq dan sedekah sehingga diharapkan keseimbangan pengetahuan keuangan secara umum dan agamanya.

Hasil penelitian ini juga sesuai dengan penelitian sebelumnya yang dilakukan oleh Poppy dkk, bahwa terdapat pengaruh positif dan signifikan inklusi keuangan terhadap kinerja usaha kecil di Provinsi Kalimantan Timur. Literasi keuangan memberikan kemampuan untuk berekspansi, meningkatkan profitabilitas, produktivitas dan keunggulan kompetitif di Kalimantan Timur. Literasi keuangan juga dapat mengarahkan para pemilik usaha untuk mendapatkan pengetahuan keuangan dan keterampilan terkait pembuatan perencanaan bisnis, merencanakan keuangan, dan membuat keputusan investasi strategis. Pengaruh tersebut didasarkan karena pelaku usaha kecil tersebut tergabung dalam kelompok pendidikan dan pelatihan kewirausahaan Klinik Bisnis KUMKM Provinsi Kalimantan Timur dalam hal pemenuhan fasilitas kebutuhan akan literasi keuangan dalam meningkatkan kinerja usaha. ${ }^{18}$

Sama halnya dengan penelitian yang dilakukan sari dan kautsar yang menyatakan bahwa literasi keungan berpengaruh terhadap inklusi keuangan masyarakat di kota Surabaya. ${ }^{19}$. Pemahaman, persepsi dan pegetahuan yang merupakan bagian dari Islamic financial literacy mempengaruhi keputusan dalam menggunakan jasa keuangan syariah selain dari kualitas pelayanan dan instrument keuangan yang ditawarkan bank syariah. ${ }^{20}$

\section{Pengaruh penggunaan fintech terhadap financial inclusion UMKM kawasan pondok pesantren di kota Jombang}

Hasil uji penelitian menunjukkan bahwa variabel penggunaan fintech (financial technology) berpengaruh terhadap financial inclusion UMKM Kawasan Pondok Pesantren di Kota Jombang. Pengaruh yang ditunjukkan dari hasil pengujian tersebut adalah positif signifikan menunjukkan hubungan yang searah antara variable penggunaan fintech dan financial inclusion, yang berarti jika terjadi perubahan terhadap penggunaan fintech maka akan mempengaruhi financial inclusion UMKM tersebut. Secara umum hasil deskripsi responden menunjukkan penggunaan fintech oleh pelaku UMKM di kawasan pondok pesantren di kota Jombang masih rendah meskipun beberapa pelaku UMKM merasa sangat terbantu dengan memanfaatkan fintech dalam kegiatan usahanya. Kemudahan dalam mengakses dan mejalankan layanan fintech menjadi keunggulan tersendiri bagi pelaku UMKM tersebut, sedangkan yang menjadi poin rendah dalam penggunaan fintech ini adalah mereka tidak dapat menggunakannya setiap saat ataupun tidak bisa mnggunakan semua layanan fintech yang tersedia, sesuai dengan hasil observasi sebelumnya yang didapatkan bahwa sebagian besar pelaku UMKM menggunakan layanan fintech berupa tabungan ataupun mobile banking untuk menunjang keperluan transfer.

\footnotetext{
${ }^{18}$ Poppy Alvianolita Sanistasya, Kusdi Raharjo, and Mohammad Iqbal, 'The Effect of Financial Literacy and Financial Inclusion on Small Enterprises Performance in East Kalimantan', Jurnal Economia, 15.1 (2019): 48-59

${ }^{19}$ Adinda Novita Sari and Achmad Kautsar, 'Analisis Pengaruh Literasi Keuangan, Financial Technology, Dan Demografi Terhadap Inklusi Keuangan Pada Masyarakat Di Kota Surabaya', Jurnal Ilmu Manajemen Universitas Negeri Surabaya, 8.2, (2020). h. 8

${ }^{20}$ Zunaira Zaman and others, 'Role of Islamic Financial Literacy in the Adoption of Islamic Banking Services: An Empirical Evidence from Lahore, Pakistan', Journal of Islamic Business and Management (JIBM), 7.2 (2017): 230-47
} 
Bentuk penggunaan financial technology yang pertama yaitu penggunaan sistem pembayaran melalui pihak ketiga seperti memakai sistem pembayaran online seperti mobile banking, ovo, gopay, dana, dan lain lain dengan tujuan untuk mempermudah traksaksi untuk menunjang kelancaran usaha. Beberapa pelaku UMKM belum memanfaatkan secara maksimal system permbayaran tersebut, masih terdapat pelaku UMKM yang belum menggunakan system pembayan dari pihak ketiga ini. Kedua yaitu Peer to peer lending antara lain yaitu manajemen resiko keuangan, pemenuhan kebutuhan modal melalui layanan kredit jasa fintech dan pembiayaan online. Sebagian besar pelaku UMKM tersebut masih belum menggunakan jasa ini untuk pemenuhan dana tabahannya. Ketiga yaitu crowdfunding terkait pengelolaan sumber pendanaan melalui platform online. Namun dari hasil pendalaman observasi yang dilakukan dari kedua indikator fintech berupa Peer to peer lending dan crowdfunding masih kurang dimanfaatkan oleh pelaku UMKM di kawasan pondok pesantren di kota Jombang dikarenakan untuk kebutuhan pendanaan masih mengandalkan keuangan pribadi dan layanan kredit perbankan di sekitarnya

Hasil penelitian ini sejalan dengan penelitian yang dilakukan oleh Mulasiwi dan Julialevi, bahwa layanan keuangan berbasis fintech memiliki pengaruh yang positif terhadap literasi keuangan dan inklusi keuangan usaha menengah di Purwokerto. Selain itu, dapat pula dibuktikan melalui hasil penelitian bahwa layanan keuangan berbasis fintech diperlukan masyarakat untuk memperluas wawasannya terkait literasi keuangan dan inklusi keuangan. Penelitian tersebut diharapkan dapat membangun kesadaran pelaku usaha menengah bahwa fintech akan mempermudah kepraktisan dalam melakukan kredit, pembayaran tagihan dan pengecekan pembayaran dengan cepat dan mudah. Sejalan dengan program Otoritas Jasa Keuangan (OJK) dalam upaya meningkatkan tingkat literasi keuangan dan inklusi keuangan. ${ }^{21}$

\section{Pengaruh islamic financial literacy dan penggunaan fintech terhadap financial} inclusion UMKM kawasan pondok pesantren di kota Jombang

Menunjukkan bahwa Islamic financial literacy dan penggunaan fintech berpengaruh terhadap financial inclusion UMKM kawasan pondok pesantren di Kota Jombang. Pengaruh positif dan signifikan secara simultan variable Islamic financial literacy dan penggunaan fintech terhadap financial inclusion memberikan makna bahwa jika terjadi perubahan pada variable Islamic financial literacy dan penggunakan fintech, maka akan menyebabkan perubahan financial inclusion UMKM kawasan pondok pesantren di kota Jombang. Nilai determinasi yang besar berdasarkan hasil uji statistic menunjukkan bahwa Islamic financial literacy dan penggunaan fintech memberikan pengaruh yang cukup besar pula terhadap financial inclusion. Adanya pemahaman dan pengelolaan keuangan yang baik berdasar pengalaman bisnis yang telah dijalankan memberikan gambaran bahwa literasi keuangan UMKM secara umum sudah dilaksanakan. Ditunjang pula dengan pemahaman ilmu agama, kombinasi tersebut menjadikan Islamic financial literacy sebagai pengembangan dari literasi keuangan dapat diterapkan dalam pengelolaan keuangannya. Sedangkan penggunaan teknologi sebagai bentuk penerapan financial technology juga dapat digunakan oleh UMKM dalam aktivitas keuangannya terutama untuk mempermudah pengelolaan keuangan bisnis. Sehingga kedua varibel tersebut memberikan pengaruh yang cukup besar terhadap financial inklusi UMKM kawasan pondok pesantren di kabupaten Jombang.

\footnotetext{
${ }^{21}$ Karina Odia Mulasiswi, Cut Musni; Julialevi, 'Optimalisasi Financial Teknologi ( Fintech ) Terhadap Peningkatan Literasi Dan Inklusi Keuangan Usaha Menengah Purwokerto’, Performance, 27.1 (2020): 12-20.
} 
Akses yang terjangkau dan kemudahan menjalakan layanan jasa keuangan yang tersedia turut menunjang financial inclusion UMKM tersebut. Selain itu penggunaan produk dan jasa keuangaan yang aman dan nyaman, lengkap dengan berbagai atributnya dan dapat menyesuaiakan kebutuhan transaksi juga termasuk dalam komponen financial inclusion. Kualitas layanan jasa keuangan juga tidak kalah penting, karena layanan jasa keuangan yang berkualitas akan dapat menunjang dan meningkatakan aktifitas usaha serta dapat mempengaruhi perilaku transaksinya misalnya melalui proses pembayarannya dan lain sebagainya. Sehingga segala kemudahan tersebut diharapkan dapat mempengaruhi kesejahteraan dan bermanfaat untuk sirkulasi keuangan pribadi maupun usaha. Sebagaimana yang diungkapkan oleh Nuryakin bahwa perpaduan layanan keuangan dan teknologi atau financial technology memberikan banyak keuntungan bagi penggunanya. Financial technology dapat memberikan berbgai macam pilihan dalam pemenuhan kebutuhan, kualitas yang lebih baik dan harga yang terjangkau. Selain itu financial technology dpat memberikan keuntungan untuk system keuangan, seperti desentralilsasi dan diversifikasi. Sedangkan untuk perekonomian, financial technology dapat mendukung transmisi kebijakan moneter, meningkatkan perputaran uang dan menambah pertumbuhan ekonomi. ${ }^{22}$

Hasil ini juga sejalan dengan penelitian Sohilaw, berdasarkan hasil pengolahan data diketahui bahwa adanya bentuk moderasi (kerjasama) antara literasi keuangan, struktur modal serta inklusi keuangan. walaupun pada kenyataanya belum berjalan dengan maksimal, inklusi keuangan terbukti secara teoritis maupun secara statistik mempengaruhi struktur permodalan UKM. Hasil penelitian juga membuktikan pengaruh literasi keuangan terhadap struktur modal, literasi keuangan terhadap inklusi keuangan dan inklusi keuangan terhadap struktur modal berpengaruh positif dan signifikan secara teoritis dan statistik. ${ }^{23}$

\section{Simpulan}

Hasil penelitian ini menunjukkan bahwa Islamic financial literacy berpengaruh positif dan signifikan terhadap financial inclusion. Penggunaan fintech berpengaruh positif dan signifikan terhadap financial inclusion UMKM. Islamic financial literacy dan penggunaan fintech berpengaruh positif dan signifikan terhadap financial inclusion UMKM kawasan pondok pesantren di Kota Jombang. Adanya nilai koefisien determinasi yang besar dari variable Islamic financial literacy dan penggunaan fintech terhadap financial inclusion menunjukkan Islamic financial literacy dan penggunaan fintech sangat bermanfaat bagi pelaku UMKM untuk meningkatkan inklusi keuangannya meskipun berdasarkan hasil deskripsi penelitian ini tingkat Islamic financial literacy dan penggunaan fintech masih dalam kategori rendah. Dengan hasil tersebut seharusnya para pelaku UMKM kawasan pondok pesantren di Kota Jombang dapat terus memanfaatkan layanan jasa keuangan melalui financial teknologi yang telah tersedia dan mengkombinasikannya dengan Islamic financial literacy untuk dapat meningkatkan transaksi keuangan usaha dan pengelolaan keuangan usaha. Terlebih lagi dalam masa pandemic covid 19 sekarang ini, penggunaan fintech dapat dilakukan secara tepat, maksimal dan terarah agar dapat meningkatkan layanan pemabaran khususnya dan terutama meminimalisir penyebaran covid 19 .

${ }^{22}$ Chaikal Nuryakin and others, 'Financial Technology in Indonesia: A Fragmented Instrument for Financial Inclusion?', May, 2019, 1-9.

${ }^{23}$ Muhammad Irfai Sohilauw, 'Jurnal Bisnis Dan Manajemen (Jbima)Moderasi Inklusi Keuangan Terhadap Hubungan Literasi Keuangan Dan Keputusan Struktur Modal UKM', Jurnal Bisnis Dan Manajemen (Jbima), 2.031 (2019) 


\section{Daftar Pustaka}

Ansori, Miswan. 'Perkembangan dan Dampak Financial Technology (Fintech) terhadap Industri Keuangan Syariah di Jawa Tengah', Wahana Islamika: Jurnal Studi Keislaman, 5.1 (2019): 31-45

Antara, Purnomo M., Rosidah Musa, and Faridah Hassan. 'Bridging Islamic Financial Literacy and Halal Literacy: The Way Forward in Halal Ecosystem', Procedia Economics and Finance, 37.16 (2016):196-202

Ekonomi, Departemen, and Keuangan. Literasi Ekonomi Syariah. Departemen Ekonomi dan Keuangan Syariah: Bank Indonesia, 2020

Er, Bunyamin. 'Financial Inclusion and Islamic Finance: A Survey of Islamic Financial Literacy Index', Uluslararası İslam Ekonomisi ve Finansı Araştırmaları Dergisi, 3.2 (2017)

Ghozali. Aplikasi Analisis Multivariete Dengan Program IBM SPSS. Semarang: Badan Penerbit Universitas Diponegoro, 2016

Indonesia, Perbankan. 'Booklet Perbankan Indonesia 2016', Otoritas Jasa Keuangan Departemen Perijinan Dan Informasi Perbankan, 3 (2016): 292

Mulasiswi, Cut Musni; Julialevi, Karina Odia, 'Optimalisasi Financial Teknologi ( Fintech ) terhadap Peningkatan Literasi dan Inklusi Keuangan Usaha Menengah Purwokerto', Performance, 27.1 (2020): 12-20

Nuryakin, Chaikal, Lovina Aisha, Natanael Waraney, and Gerald Massie, 'Financial Technology in Indonesia: A Fragmented Instrument for Financial Inclusion?', LPEM-FEB UI Working Paper 036 (2019): 1-9

Rahim, S. H. A., Rashid, R. A., Hamed, A. B, 'Factor Analysis of Islamic Financial Literacy and Its Determinan: A Pilot Study', International Soft Science Conference (ISSC), (2016)

Riset, Jurnal, Muhadjir Anwar, Eko Purwanto, and Kata Kunci, 'Keuangan Inklusif dan Literasi Keuangan ( Studi Pada Sentra Industri Kecil Di Jawa Timur )', 17.2 Journal Of Research In Economics And Management, 17.2 (2017): 273-82

Sanistasya, Poppy Alvianolita, Kusdi Raharjo, and Mohammad Iqbal, 'The Effect of Financial Literacy and Financial Inclusion on Small Enterprises Performance in East Kalimantan', Jurnal Economia, 15.1 (2019): 48-59

Sari, Adinda Novita, and Achmad Kautsar, 'Analisis Pengaruh Literasi Keuangan, Financial Technology dan Demografi Terhadap Inklusi Keuangan Pada Masyarakat Di Kota Surabaya', Jurnal Ilmu Manajemen Universitas Negeri Surabaya, 8.4 (2020)

Setiawati, Rike, Sulaeman Rahman Nidar, Mokhamad Anwar, and Dian Masyita, 'Islamic Financial Literacy: Construct', Academy of Strategic Management Journal, 17.4 (2018):1-12

SNKI, Buletin, 'Negara Hadir Perkuat Ekonomi Kerakyatan Melalui Kur Khusus Peternakan Rakyat', (2019): 1-10

Sohilauw, Muhammad Irfai, 'Moderasi Inklusi Keuangan Terhadap Hubungan Literasi Keuangan Dan Keputusan Struktur Modal UKM', Jurnal Bisnis Dan Manajemen (Jbima), 2.31 (2019)

Sugiyono, Metode Penelitian Kuantitatif, Kualitatif, Dan R\&D, Bandung: Alfabetha, 2015

UMKM, Departemen Pengembangan Akses Keuangan, Booklet Keuangan Inklusif, Bank Indonesia, 2016 
Xue, Peng, Zhibin Wang, Rui Zhang, Yaoli Wang, and Shun Liu, 'Highly Efficient Measurement Technology Based on Hyper-Spectropolarimetric Imaging', Zhongguo Jiguang/Chinese Journal of Lasers, 43.8 (2016): 107-28

Zaman, Zunaira, Bilal Mehmood, Rashid Aftab, Muhammad Shahid, and Yasir Ameen, 'Role of Islamic Financial Literacy in the Adoption of Islamic Banking Services: An Empirical Evidence from Lahore, Pakistan', Journal of Islamic Business and Management (JIBM), 7.2 (2017): 230-47 